20

\title{
Дифракция и волноводное распространение света в эмали зуба
}

\author{
(C) В.Н. Грисимов \\ Первый Санкт-Петербургский государственный медицинский университет им. академика И.П. Павлова, \\ 197022 Санкт-Петербург, Россия \\ e-mail: vngrisimov@gmail.com
}

Поступила в редакцию 07.08.2019 г.

В окончательной редакции 21.02.2020 г.

Принята к публикации 15.03.2020 г.

На продольных меридиональных шлифах удаленных зубов исследовано распространения света в эмали зуба. Показано, что распространение света в эмали зависит от угла падения светового пучка относительно направления эмалевых призм. При падении лазерного пучка на эмаль перпендикулярно плоскости шлифа можно наблюдать упорядоченную картину дифракции на периодических неоднородностях, которые представлены параллельно расположенными внешними участками эмалевых призм. При падении лазерного пучка на поверхность зуба в плоскости шлифа картину распространения лазерного излучения в эмали можно объяснить волноводным распространением света по эмалевым призмам. На основе волноводной модели объясняются условия проявления известного оптического эффекта в виде полос Гунтера-Шрегера в отраженном и проходящем свете. Установлено, что наличие или отсутствие дифракционной картины, соответствующей дифракции на периодических неоднородностях эмали зуба, зависит от возраста зуба и толщины шлифа. Полученные данные позволяют сделать вывод о характере возрастной минерализации эмали в процессе ее созревания, которая приводит к увеличению прозрачности эмали и уменьшению степени ее оптической анизотропии.

Ключевые слова: дифракция, волноводное распространение света, возрастные изменения эмали зуба.

DOI: $10.21883 /$ OS.2020.08.49735.245-19

\section{Введение}

Повышенный интерес к изучению оптических характеристик твердых тканей зуба в современной стоматологии обусловлен применением методик прямых эстетических реставраций зубов светоотверждаемыми материалами, а также использованием оптических методов диагностики поражений зубов. Эмаль и дентин благодаря наличию упорядоченных структур являются анизотропными оптическими средами, в которых соотношение пропускания и рассеяния света обусловлено направлением падающего светового потока по отношению к данным структурам. В связи с этим исследование оптических эффектов в твердых тканях зуба, обусловленных анизотропией, позволяет уточнить морфологические особенности твердых тканей зуба, имеющие значение для работы клиницистов.

Эмаль - самая твердая и устойчивая к механическим нагрузкам ткань организма, покрывающая анатомическую коронку зуба. Толщина эмали варьирует от $0.1 \mathrm{~mm}$ в области шейки зуба до $2 \mathrm{~mm}$ в области жевательной поверхности. Около 95\% массы (87\% объема) здоровой зрелой эмали составляют минеральные вещества, около $4 \%$ массы $(11.5 \%$ объема $)$ - связанная и свободная вода, около $1 \%$ массы (1.5\% объема) - органические вещества [1]. Последние образуют матрицу, обеспечивающую упорядоченность структуры эмали. Влияние органической матрицы на оптические характеристики эмали невелико: вероятно, она отвечает за явления люминесценции [2].

Оптически значимыми структурными элементами эмали являются эмалевые призмы и кристаллы апатитов.

Кристаллы апатитов похожи на уплощенные палочки, имеющие в поперечном сечении гексагональную форму. Длина кристаллов зрелой эмали составляет приблизительно от 500 до $1000 \mathrm{~nm}$, а средний диаметр 50-100 nm [3]. Расстояние между кристаллами зрелой здоровой эмали по данным различных авторов составляет от $1-2 \mathrm{~nm}$ [1] до $5 \mathrm{~nm}$ [4].

Кристаллы формируют более крупные структурные элементы - эмалевые призмы (называемые также „эмалевыми стержнями“), проходящие через всю толщу эмали от дентиноэмалевого соединения (ДЭС) до поверхности эмали. Проекции эмалевых призм на горизонтальные плоскости сечения зуба имеют радиальные направления. В меридиональных сечениях ориентация призм зависит от их расположения. У шейки зуба призмы ориентированы горизонтально. По мере приближения к верхушке бугра или режущему краю положение призм отклоняется к вертикальной оси зуба. В области внутренних скатов бугров премоляров и моляров призмы ориентированы перпендикулярно поверхности ДЭС. Во внутренней половине слоя эмали призмы имеют синусоидальные изгибы. Вследствие этого направление одной и той же призмы может несколько раз меняться. При этом призма, делая синусоидальные изгибы, имеет углы отклонения от своего общего направления до 
$20^{\circ}$ [5]. В пришеечной трети синусоидальные изгибы распространяются на всю толщину эмали. В области режущего края и верхушки бугра изгибы призм имеют спиралевидный характер [6]. На поперечных разрезах призм виден гексагональный порядок их расположения относительно друг друга [4]. Поперечный размер призм увеличивается по мере удаления от ДЭС к поверхности эмали. Наиболее часто форма поперечного сечения призм имеет вид „замочной скважины“. Широкая часть замочной скважины (головка или тело призмы) ориентирована в сторону режущего края или вершины бугра, а узкая часть (отросток) - в сторону шейки зуба. Средний диаметр головки призмы составляет $5 \mu \mathrm{m}$, а общая длина головки с отростком (длина „замочной скважины“ ) - до $9 \mu \mathrm{m}[7]$.

Ориентация кристаллов в призме определяется местом их расположения. В теле призмы кристаллографические (они же - оптические) оси кристаллов совпадают с продольной осью призмы, а сами кристаллы относительно плотно прилегают друг к другу. У границ призм оси кристаллов отклоняются. В отростках это отклонение достигает $60-70^{\circ}$ относительно направления призмы. Между призмами располагается межпризменное вещество, которое в эмали зубов человека имеет толщину около $0.1 \mu \mathrm{m}$ [1]. В межпризменном веществе кристаллы апатитов менее плотно упакованы и расположены хаотично. Поэтому степень минерализации межпризменного вещества ниже, чем самих призм. Различие в степени минерализации призм и межпризменного вещества обусловливает наличие разности показателя преломления: его значение в межпризменном веществе меньше, чем в теле призмы. Призмы собраны в пучки, диаметр которых состоит из 10-12 призм.

Особенности строения эмали определяют ее оптические свойства и позволяют наблюдать специфические оптические эффекты, проявляющиеся на шлифах зубов.

Оптический эффект в виде полос Гунтера-Шрегера (ГШ) представляет собой проявление оптической анизотропии эмали, которая обусловлена изгибами призм [4]. Эти полосы идут от дентина к поверхности эмали и выявляются при исследовании продольных шлифов зубов в отраженном свете. Темные полосы, так называемые диазоны, соответствуют участкам эмалевых призм, ориентация которых почти совпадает с направлением падающего света. Светлые полосы, так называемые паразоны, соответствуют участкам эмалевых призм, которые образуют с направлением падающего света углы, наиболее близкие к $90^{\circ}$. Чередование темных и светлых полос более выражено во внутренней половине слоя эмали. В отраженном свете полосы ГШ видны не только на шлифах, но и на продольных распилах. Полосы ГШ пересекают направления призм под острым углом, отклоняясь при этом к шейке зуба. Полосы ГШ не выявляются в области режущих краев резцов, вершин бугров клыков, премоляров и моляров, где изгибы призм имеют спиралевидный характер, т.е. там, где призмы изгибаются в разных плоскостях.
Оптический эффект в виде линий Ретциуса на вертикальных шлифах представляет собой тонкие полосы, идущие тангенциально поверхности эмали с выходом на нее. Они выявляются в виде темных полос в проходящем свете и в виде светлых полос в отраженном свете. На горизонтальных шлифах линии Ретциуса проявляются в виде концентрических колец, центры которых расположены на вертикальной оси коронки зуба. Это оптический эффект, обусловленный чередованием участков нормальной и пониженной минерализации по ходу призмы. Разная минерализация обусловливает разную пористость и соответственно разную величину пропускания и рассеяния света [4].

В целом для света видимого диапазона эмаль является слабо поглощающей, рассеивающей средой, обусловливающей относительную белизну зубов. С возрастом цвет зубов несколько меняется: светлота уменьшается, а цвет приобретает желтый оттенок за счет просвечивающего дентина. Такое изменение эстетики происходит из-за увеличения прозрачности эмали вследствие ее возрастной минерализации. Очевидно, что возрастная минерализация эмали оказывает влияние на особенности ее структуры, что, в свою очередь, должно проявляться в изменении оптических характеристик.

Целью настоящей работы явилось исследование проявлений оптической анизотропии эмали зубов разных возрастных групп.

\section{Материалы и методы}

\section{Исследование распространения света в эмали зуба поперек направления эмалевых призм}

Для исследования использовались интактные зубы, удаленные по ортодонтическим показаниям в сроки от одного до трех лет после прорезывания (первая группа зубов) и в сроки от тридцати до шестидесяти лет после прорезывания (вторая группа зубов). Первая группа включала премоляры и третьи моляры верхней и нижней челюстей. Вторая группа включала зубы всех анатомических групп: резцы, клыки, премоляры и моляры верхней челюсти; клыки, премоляры и моляры нижней челюсти. Из зубов готовились плоскопараллельные вертикальные шлифы, соответствующие одной из меридиональных плоскостей: вестибуло-оральная для резцов и клыков, вестибуло-оральная или мезиодистальная - для премоляров, диагональная - для моляров. Механическая обработка поверхностей шлифа абразивами (шлифовка и полировка) осуществлялась на твердой основе. Последняя позволяла предотвратить образование микрорельефа при использовании мягкой основы из-за разной устойчивости эмали к абразивному воздействию в зависимости от ориентации фрагментов призм к плоскости образца [8]. Шлиф зуба помещался в стеклянную кювету, заполненную водой. Пучок света от 532-nm твердотельного лазера с диодной накачкой, пройдя через точечную диафрагму диаметром $230 \mu \mathrm{m}$, 

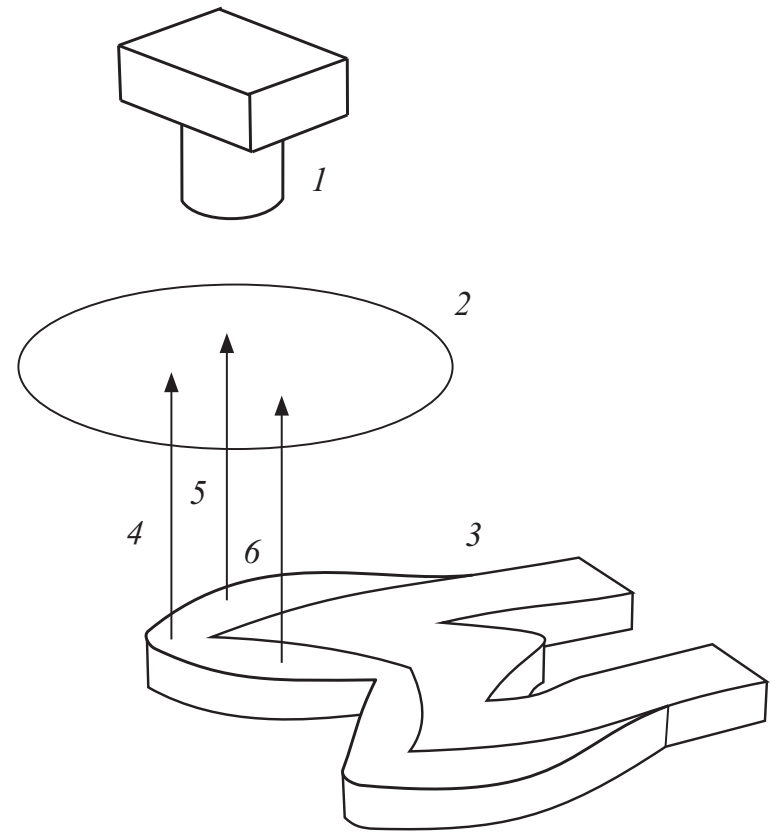

Рис. 1. Схема экспериментальной установки: $1-$ фотоаппарат, 2 - экран, 3 - шлиф коронковой части зуба, 4, 5, 6 области прохождения лазерного пучка.

падал на примыкающую к диафрагме поверхность шлифа со стороны дна кюветы. Прошедший через внешнюю часть слоя эмали световой поток попадал на экран, расположенный на расстоянии $14 \mathrm{~mm}$ от шлифа. Проводилась визуальная оценка и фотографирование дифракционной картины, образуемой на экране световым потоком, вышедшим из шлифа, по мере истончения шлифа с шагом $20 \mu \mathrm{m}$ от толщины 1200 до $300 \mu \mathrm{m}$. Схема экспериментальной установки представлена на рис. 1. Диафрагма и кювета на рис. 1 не показаны.

\section{Исследование распространения света в эмали зуба вдоль направления эмалевых призм}

Для второго исследования из премоляров верхней челюсти аналогичным образом готовились шлифы толщиной $120 \mu \mathrm{m}$. Плоскость шлифа соответствовала вестибуло-оральному (щечно-небному) вертикальному сечению и проходила через середину коронки. Для исследования использовалась экспериментальная установка, представленная на рис. 2. Шлиф зуба помещался в стеклянную цилиндрическую кювету, заполненную водой. Пучок света от того же лазерного источника падал на поверхность эмали, пройдя через щелевую диафрагму, расположенную на расстоянии $10 \mathrm{~mm}$ от шлифа. Кювета и диафрагма на рис. 2 не показаны. Под кюветой помещалась поворотная призма. Белый свет от источника 7 падал на поверхность шлифа под углом от 60 до $70^{\circ}$. При положении фотоаппарата 1 проводилось фотографирование поверхности шлифа, обращенной вверх. При положении фотоаппарата 2 за счет поворотной призмы проводилось фотографирование поверхности шлифа, обращенной вниз. Обязательными условиями фотографирования верхней и нижней поверхностей шлифа были параллельность горизонтального перемещения оптической оси объектива фотоаппарата лазерному лучу и треугольным граням призмы. Для получения изображений одинакового размера при изменении положения фотоаппарата $(1 \rightarrow 2)$ его перемещали не только в горизонтальной плоскости, но и по оптической оси объектива, приближая к горизонтальной поверхности призмы и не меняя фокусировку объектива.

Для сравнительного анализа изображений верхней и нижней поверхностей шлифа в области вхождения лазерного пучка использовался графический редактор Paint Shop Pro X6. C помощью команды „Перевернуть по горизонтали“ из действительного изображения нижней поверхности получали ее зеркальное изображение. Затем из действительного изображения верхней поверхности и зеркального изображения нижней поверхности выделялся один и тот же участок. Для выделения идентичных участков их координаты „привязывались“ к реперным точкам, в качестве которых использовались трещины шлифа.

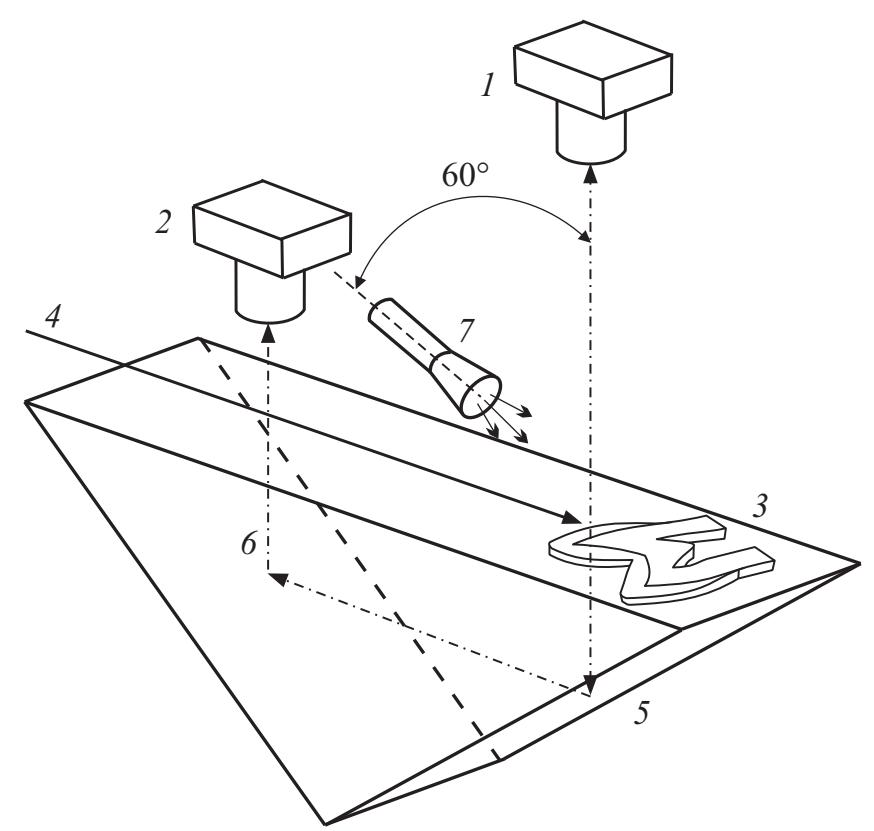

Рис. 2. Схема экспериментальной установки: 1 - положение фотоаппарата при фотографировании поверхности шлифа, обращенной вверх; 2 - положение фотоаппарата при фотографировании поверхности шлифа, обращенной вниз; 3 шлиф коронковой части зуба, первый премоляр верхней челюсти, вестибуло-оральное сечение; 4 - лазерный пучок, пучок направлен на оральную (небную) поверхность эмали и находится в плоскости шлифа; 5, 6 - отражающие грани призмы, образующие между собой угол $90^{\circ} ; 7-$ источник белого света для наблюдения шлифа в отраженном свете при его косом падении на поверхность шлифа со стороны небной поверхности эмали. 


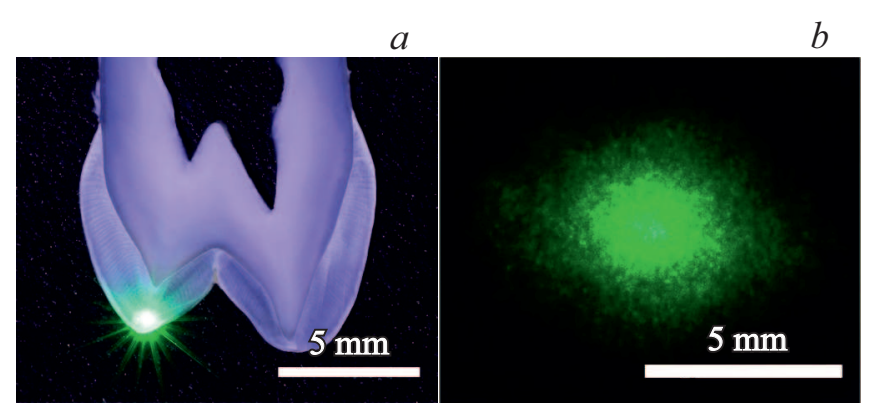

Pис. 3. Прохождение лазерного излучения при падении пучка перпендикулярно плоскости шлифа верхнего первого премоляра в области верхушки небного бугра (a). Соответствующая картина рассеяния лазерного излучения, наблюдаемая на экране после прохождения пучка через эмаль верхушки бугра $(b)$.

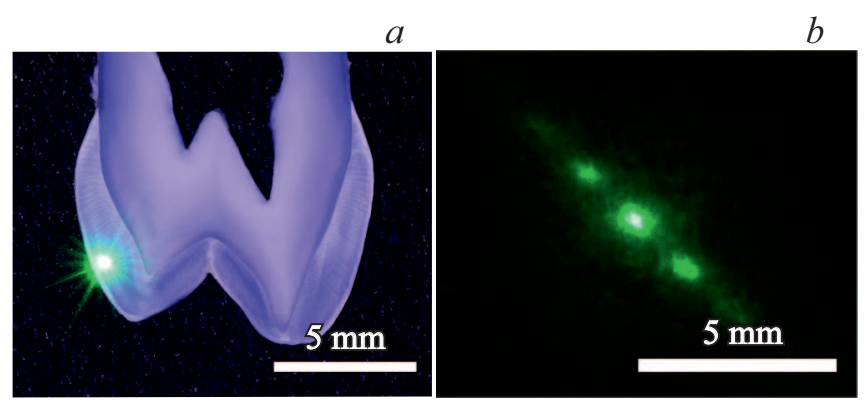

Рис. 4. Прохождение лазерного излучения поперек эмалевых призм при падении пучка перпендикулярно плоскости того же шлифа в области небной поверхности $(a)$. Соответствующая дифракционная картина, наблюдаемая на экране после прохождения лазерного пучка поперек направления эмалевых призм; максимумы интенсивности выстроены в линию перпендикулярно направлению призм в данной области $(b)$.

\section{Результаты}

\section{Характер распространения света в эмали зуба поперек направления эмалевых призм}

При падении лазерного пучка поперек направления эмалевых призм (рис. 1) характер дифракционной картины на экране зависел от возраста зубов, толщины шлифа и участка прохождения пучка. На шлифах разной толщины (от 1200 до $300 \mu \mathrm{m}$ ) зубов любого возраста (вторая группа) при прохождении лазерного пучка через эмаль в области режущего края резцов или верхушки бугра клыков, премоляров и моляров на экране можно было увидеть световое пятно с размытыми границами, интенсивность которого возрастала по мере истончения шлифа (рис. 3). Аналогичное пятно выявлялось на шлифах толщиной от 1200 до $300 \mu \mathrm{m}$ во всех указанных на рис. 1 точках 4, 5, 6 прохождения лазерного пучка у зубов, удаленных в сроки от одного до трех лет после прорезывания (первая группа).
На шлифах зубов второй группы при прохождении лазерного пучка через эмаль в области вестибулярной, оральной, аппроксимальной, а также жевательной поверхностей на экране можно было наблюдать дифракционную картину в виде цепочки из световых пятен, выстроенных в линию, перпендикулярную направлению призм (рис. 4,5). При этом выявляемость дифракционной картины в виде выстроенных в цепочку световых пятен была связана с двумя взаимозависимыми факторами: возрастом зуба и толщиной шлифа. С увеличением возраста зуба дифракционная картина выявлялась при увеличении толщины шлифа. Так, у зубов, удаленных в сроки 50-60 лет после прорезывания, дифракционная картина наблюдалась на шлифах толщиной $1200-1100 \mu \mathrm{m}$. На одних зубах она могла наблюдаться при истончении шлифа до толщины $1000-950 \mu \mathrm{m}$, а на других - утрачивала дискретность в виде хорошо различимых порядков дифракции. У зубов, удаленных в сроки от 30 до 50 лет после прорезывания, данная дифракционная картина наблюдалась при толщине шлифов от 900 до $320 \mu \mathrm{m}$. При этом, чем моложе зуб, тем меньше требовалась толщина шлифа.

При уменьшении толщины шлифа выявленная дифракционная картина постепенно менялась. Границы порядков расширялись, главным образом, за счет нулевого порядка, в результате чего происходило взаимное перекрытие порядков дифракции. Данная динамика изменения дифракционной картины представлена на рис. 6.

\section{Характер распространения света в эмали зуба вдоль эмалевых призм}

Результаты исследования характера распространения света вдоль эмалевых призм на шлифах премоляров верхней челюсти толщиной 120 мкм представлены на рис. 7. На рис. 7 видны два вида светлых полос: 1) тонкие полосы, идущие тангенциально поверхности зуба (линии Ретциуса), 2) более широкие серповидно изогнутые полосы, идущие от дентина к поверхности зуба (полосы

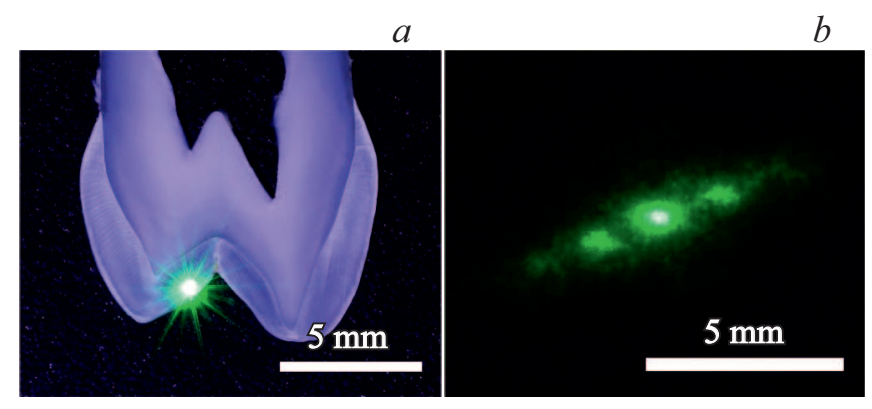

Рис. 5. Прохождение лазерного излучения поперек эмалевых призм при падении пучка перпендикулярно плоскости того же шлифа в области внутреннего ската небного бугра $(a)$. Соответствующая дифракционная картина, наблюдаемая на экране после прохождения лазерного пучка; максимумы интенсивности выстроены в линию перпендикулярно направлению призм $(b)$. 


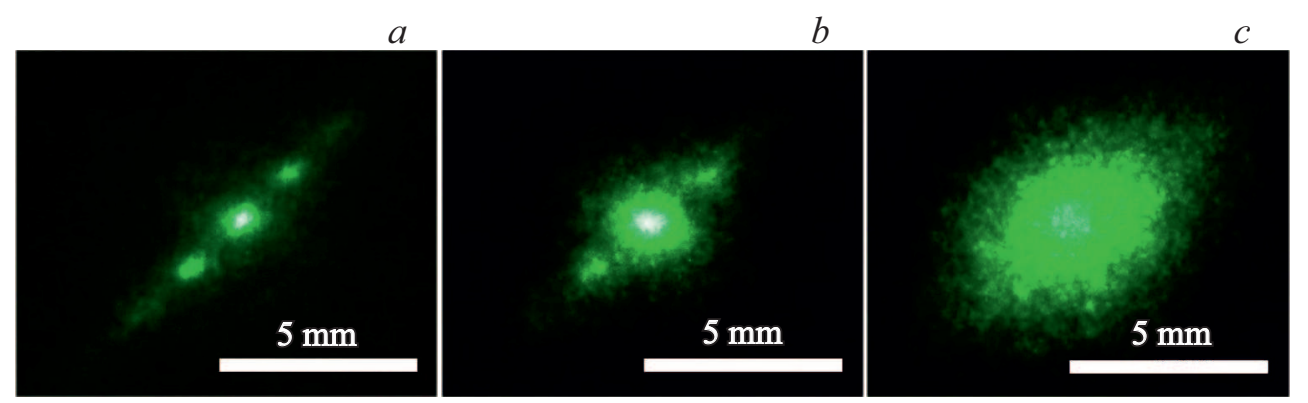

Рис. 6. Динамика изменения дифракционной картины при уменьшении толщины шлифа. Первоначальный вид дифракционной картины: нулевой и первые порядки дифракции хорошо различимы $(a)$. При уменьшении толщины шлифа границы порядков расширяются $(b)$, перекрывая в итоге друг друга $(c)$.

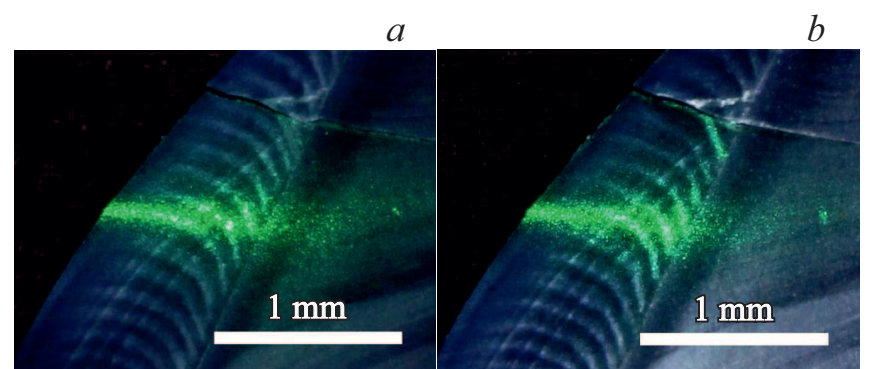

Рис. 7. Картина полос ГШ при подсветке пучком лазера и источником света 7. Поверхность шлифа, обращенная вверх $(a)$. Поверхность шлифа, обращенная вниз, зеркальное изображение $(b)$.

ГШ). Из представленных фотографий видно, что при подсветке шлифа лазерным лучом картина бокового рассеяния его излучения во внутренней половине слоя эмали соответствует рисунку полос ГШ. При косом падении света на поверхность плоскости шлифа со стороны небной поверхности эмали картина бокового рассеяния света лазерного источника своими максимумами совпадает со светлыми полосами, которые обусловлены светом источника 7. Сравнение фотографий, представленных на рис. 7, $a$ и $b$, показывает полное несовпадение проекций распределения светлых и темных полос как от лазера, так и от источника 7. Проекциям светлых полос ГШ верхней поверхности шлифа соответствуют темные полосы нижней поверхности шлифа. При этом координаты светлых линий Ретциуса верхней и нижней поверхностей совпадают.

\section{Обсуждение}

При падении лазерного пучка на эмаль перпендикулярно плоскости шлифа имеет место рассеяние и дифракция света на кристаллах гидроксиапатита и на эмалевых призмах. В незрелой эмали превалирует рассеяние на неоднородностях „кристаллы гидроксиапатита - межкристаллические пространства“. Поэтому вне зависимости от толщины шлифа и места падения лазерного пучка на эмаль зубов первой группы на экране получалась дифракционная картина в виде светового пятна с размытыми границами (рис. $3, b$ ).

В незрелой эмали размеры кристаллов меньше, а расстояния между кристаллами больше, чем в зрелой эмали [9]. Незрелая эмаль содержит больше воды и органических веществ. В процессе созревания уровень минерализации эмали увеличивается, а количество воды и органических веществ уменьшается [10]. За счет увеличения размеров кристаллов вследствие их роста и слияния уменьшаются расстояния между ними [9]. Процесс созревания эмали в виде отложения минералов начинается до прорезывания зуба и продолжается после его прорезывания в течение всей жизни. Неравномерное отложение минералов в процессе созревания приводит к тому, что еще до прорезывания формируется разная степень минерализации призм и межпризменного вещества [11]. Такое различие в степени минерализации сохраняется и после прорезывания, что обусловливает различие показателя преломления призм и межпризменного вещества у зрелой эмали. По расчетным данным при объемном количестве минеральных веществ призм $88 \%$ и межпризменного вещества 70\% показатель преломления призм составляет 1.619, а межпризменного вещества - 1.573 [12].

В зрелой эмали рассеяние на неоднородностях „кристаллы гидроксиапатита-межкристаллические пространства“ должно уменьшаться. Это позволяет наблюдать упорядоченную дифракционную картину как на дифракционной решетке за счет периодических неоднородностей „эмалевые призмы-межпризменное вещество“. Такая картина выявлялась на экране при прохождении лазерного пучка через участки эмали с локальной периодичностью структуры в виде параллельно расположенных участков призм, имеющих почти одно направление перпендикулярно лазерному пучку по всей толщине шлифа. У одного и того же шлифа контраст дифракционной картины при прохождении лазерного пучка через области с низким общим уровнем минерализации (линии Ретциуса) был выражен меньше, чем при прохождении вне этих областей. 
Результаты эксперимента показали, что возникновение упорядоченной дифракционной картины как на дифракционной решетке связано с двумя взаимозависимыми факторами: возрастом зуба и толщиной шлифа. С увеличением возраста зуба дифракционная картина выявлялась при увеличении толщины шлифа.

На дифракционное поле, образованное периодическими структурами (призмами), накладывается рассеянное поле, формирующееся на непериодических структурах. К последним можно отнести кристаллы на периферии призм и кристаллы в межпризменных пространствах. Поскольку с увеличением уровня минерализации происходит укрупнение кристаллов за счет их роста и слияния, а также уменьшение расстояния между кристаллами, интенсивность поля, рассеянного на непериодических структурах, должна уменьшаться. Дальнейшее отложение минеральных веществ в межпризменных пространствах в процессе возрастной минерализации должно приводить к уменьшению разности между значениями показателя преломления призм и межпризменного вещества. Вследствие этого интенсивность поля, рассеянного на периодических структурах, к которым относятся параллельно расположенные участки призм, также должна уменьшаться. Учитывая, что телесный угол рассеяния на непериодических структурах больше, чем угол дифракции на периодических структурах, условием проявления дискретных дифракционных порядков на экране являлось увеличение толщины шлифа.

При падении лазерного пучка на поверхность зуба в плоскости шлифа (рис. 2) картину распространения лазерного излучения в эмали можно объяснить волноводным распространением света по эмалевым призмам. Поскольку значение показателя преломления у призм больше, чем у межпризменного вещества, значительная часть света может распространяться внутри призмы, испытывая полное внутреннее отражение на ее границах, как это происходит внутри оптического волновода (световода) [13].

Учитывая, что максимальный угол отклонения изгиба призмы от ее общего направления составляет порядка $20^{\circ}$, а поверхность шлифа параллельна общему ходу призмы, то она пересекает изгибы пучка призм под тем же углом $20^{\circ}$ (рис. 8,a). При этом торцы пересеченных призм должны быть ориентированы к поверхности шлифа под такими же углами в двух противоположных направлениях. Если свет, падающий под углом на поверхность шлифа, попадает на торец призмы, обращенный к источнику $(5$, рис. $8, a)$, то он входит в эмаль в пределах апертурного угла призмы (световода) и распространяется внутри нее $(2$, рис. $8, a)$. В таких областях поверхности эмали образуются темные полосы. Если тот же свет падает на торец призмы, обращенный от источника $(6$, рис. $8, a)$, то он входит в призму вне апертурного угла и после преломления на поверхности шлифа попадает на внутреннюю поверхность призмы под углом меньше предельного угла полного внутреннего отражения. В данном случае свет должен выйти в
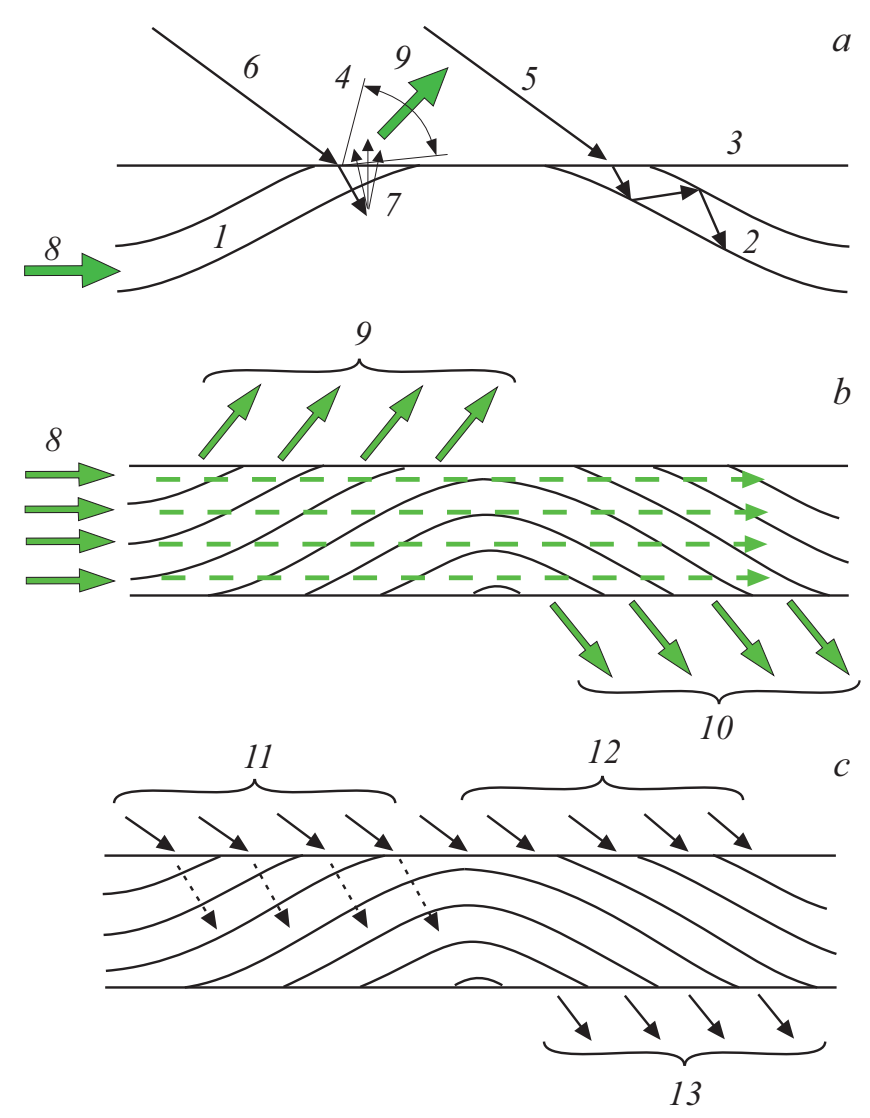

Рис. 8. Схема взаимодействия излучения лазера и косо падающего на поверхность шлифа белого света с эмалевыми призмами: 1 - наружный фрагмент призмы, пересеченный поверхностью шлифа; 2 - внутренний фрагмент призмы, пересеченный поверхностью шлифа; 3 - верхняя поверхность шлифа, пересекающая изгибы пучка призм; 4 - апертурный угол призмы; 5 - свет, падающий на торец призмы внутри апертурного угла; $6-$ свет, падающий на торец призмы вне апертурного угла; 7 - диффузное отражение света границами призм при его падении вне апертурного угла; $8-$ излучение лазера, падающее на поверхность эмали; 9 - выход излучения лазера через апертурные углы призм на верхней поверхности шлифа; 10 - выход излучения лазера через апертурные углы призм на нижней поверхности шлифа; 11 - вход косо падающего света вне апертурных углов призм; $12-$ вход косо падающего света внутри апертурных углов призм; 13 - выход косо падающего света из апертурных углов призм.

соседнюю призму, что должно приводить к увеличению диффузно отраженного светового потока, образуемого боковыми границами в пучке соседних призм, и к образованию светлой полосы. При падении лазерного пучка на внешнюю поверхность эмали (рис. 2) свет должен входить в призму внутри ее апертурного угла и в значительной мере распространяться внутри призмы как по световоду. В месте выхода торца призмы на поверхность выходит и свет от лазера (рис. 8,a). Поэтому картина бокового рассеяния света лазера своим максимумом совпадает со светлой полосой, образованной светом, падающим на поверхность шлифа со стороны небной 
поверхности (источник 7, рис. 2). Учитывая, что свет распространяется не только вдоль эмалевых призм, но и пересекает их границы, основная часть света лазера проходит через эмаль от ее поверхности к дентину соответственно направлению падающего пучка (штриховые стрелки на рис. $8, b)$. При этом свет должен выходить из шлифа, преодолевая его поверхности через апертурные углы призм. Если апертурные углы открываются вверх, то свет выходит вверх, если апертурные углы открываются вниз, то свет выходит вниз. Таким образом, если учитывать толщину шлифа $(120 \mu \mathrm{m})$, углы отклонения пучка призм и их поперечный размер, то проекции апертурных углов, открывающихся вверх, не должны совпадать с таковыми, открывающимися вниз. При косом падении света на поверхность шлифа вне апертурных углов эмалевых призм после его преломления на поверхности шлифа он проходит внутрь (рис. 8,c). При этом происходит многократное френелевское отражение на каждой границе „тело призмы-межпризменное вещество“ из-за разности показателей преломления. Прошедший таким образом световой поток на выходе через нижнюю поверхность шлифа должен быть ослаблен. Если свет падает внутри апертурных углов, световой поток проходит вдоль эмалевых призм, не испытывая вышеназванного френелевского отражения. Поэтому он меньше ослаблен и с большей интенсивностью выходит через апертурные углы нижней поверхности (рис. 8,c). В результате в проекциях светлых полос на верхней поверхности находятся темные полосы на нижней поверхности и соответственно в проекциях темных полос на верхней поверхности находятся светлые полосы на нижней поверхности (рис. 7, $a, b$ ).

Исходя из взаимодействия света с апертурными углами призм, можно объяснить, почему в подавляющем большинстве публикаций сообщается о том, что на шлифах зубов полосы ГШ видны в отраженном естественном свете и не видны в проходящем. При этом будем считать, что изгибы призм симметрично отклоняются относительно плоскости шлифа. Если свет падает под неким углом в той же азимутальной плоскости, в которой синусоидально изгибаются призмы исследуемого участка эмали, полосы ГШ видны из-за разной ориентации апертурных углов относительно падающего света. Если свет падает под неким углом в плоскости, перпендикулярной плоскости изгибов призм или по нормали к плоскости шлифа, полосы не видны из-за одинакового направления падающего света по отношению ко всем апертурным углам. В проходящем свете полосы не видны по той же причине, так как световой поток изза нормального падения также одинаково ориентирован по отношению к апертурным углам эмалевых призм.

\section{Заключение}

Проведенное исследование эмали зубов разных возрастных групп показывает, что в первую очередь за счет возрастной минерализации происходит уменьшение оптической неоднородности на уровне „кристаллы гидроксиапатита-межкристаллические пространства“. Затем происходит уменьшение оптической неоднородности на уровне „тело призмы-межпризменное вещество“. Такие изменения должны приводить к уменьшению рассеяния света эмалью и уменьшению ее оптической анизотропии. Итогом уменьшения оптической анизотропии может быть исчезновение рисунка полос ГШ на препаратах эмали [13]. Увеличение прозрачности эмали вне зависимости от направления эмалевых призм и схожие возрастные изменения дентина [14] придают зубу более выраженную многоцветность как в направлении от шейки к режущему краю или к жевательной поверхности, так и в промежутке между аппроксимальными поверхностями. В данных ситуациях при проведении прямых эстетических реставраций оправдано применение реставрационных материалов с пониженной опаковостью [15]. Кроме того, гомогенизация структуры эмали на уровне „тело призмы-межпризменное вещество“ может вносить коррективы при подготовке инструментально обработанной поверхности эмали для адгезивной техники реставрации в виде увеличения времени ее кислотного травления [16].

\section{Список литературы}

[1] Arends J., Cate J.M. // J. Crystal. Growth. 1981. V. 53. N 1. P. 135-147.

[2] Spitzer D., Bosch J.J. // Calcif. Tiss. Res. 1975. V. 17. N 1. P. 129-137.

[3] Jongenbloed W.L., Molenaar I., Arends J. // Calcif. Tiss. Res. 1975. V. 19. N 1. P. 109-123.

[4] Berkovitz B.K.B., Boyde A., Frank R.M., Hohling H.J., Moxham B.J., Nalbandian J., Tonge C.H. Teeth. Berlin: Springer-Verlag, 1989. P. 309-473.

[5] Osborn J.W. // J. Dent. Res. 1968. V. 47. N 2. P. 217-222.

[6] Osborn J.W. // J. Dent. Res. 1968. V. 47. N 3. P. 395-402.

[7] Meckel A.H., Griebstein W.J., Neal R.J. // Arch. Oral Biol. 1965. V. 10. N 5. P. 775-783.

[8] Osborn J.W. // Arch. Oral Biol. 1965. V. 10. N 6. P. 929-933.

[9] Kerebel B., Daculsi G., Kerebel L.M. // J. Dent. Res. 1979. V. 58(B). Spec. iss. P. 844-851.

[10] Goldberg M., Genotelle-Septier D., Molon-Noblot M., Weill R. // J. Biol. Buccale. 1979. V. 7. N 4. P. 353-363.

[11] Kallistová A., Horáček I., Šlouf M., Skála R., Fridrichová M. // Plos. 2017. https://journals.plos.org/plosone/ article? $\mathrm{id}=10.1371 /$ journal.pone. 0171424

[12] Zijp J.R., Bosch J.J., Groenhuis R.A.J. // J. Dent. Res. 1995. V. 74. N 12. P. 1891-1898.

[13] Grisimov V.N. // Proc. SPIE. 1999. V. 3564. P. 237-242.

[14] Грисимов В. // Эстетическая стоматология. 2016. № 1-2. C. 67-73.

[15] Грисимов В., Хиора Ж. // ДентАрт. 2013. № 1. С. 15-24.

[16] Lopes G.C., Thys D.G., Klauss P., Mussi G., Widmer N. // Compendium. 2007. V. 28. N 1. P. 662-669. 